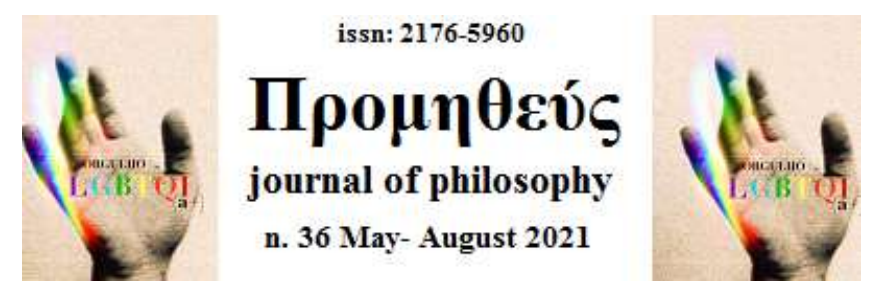

\title{
ANÁLISE DOS ARGUMENTOS JURÍDICOS PRESENTES NO PALAMEDES DE GÓRGIAS
}

\author{
Thatiane Santos Meneses \\ Universidade Federal de Sergipe
}

RESUMO: A presente pesquisa tem por objetivo fazer uma análise sobre o método do discurso empregado por Górgias em sua obra intitulada de "A Defesa de Palamedes" por meio de uma apreciação filosófica analítica do texto, tomando por base o modelo jurídico adotado na Grécia nos idos do século $\mathrm{V}$ a.C. A pesquisa tem como objetivos específicos investigar o método gorgiano de defesa na Defesa de Palamedes, identificar, na mesma obra, os elementos retóricos de persuasão empregados por Górgias, compreender os princípios jurídicos utilizados por Górgias na obra em comento e estimar qual seria a real intenção de Górgias com a apresentação da Defesa de Palamedes. Trataremos detidamente de dois pontos básicos apontados no discurso de Palamedes, que seria a ausência de provas e a verossimilhança das alegações. Será feita ainda uma abordagem de tais pontos à luz do manual de retórica proposto por Aristóteles. O tema é relevante para a compreensão do desenvolvimento das reflexões filosóficas acerca dos processos jurídicos e os meios para efetuar a persuasão. $\mathrm{O}$ entendimento desses questionamentos dos pensadores antigos lançará luz sobre as discussões atuais quanto a esses temas, nos possibilitando compreender aspectos importantes deste desenvolvimento bem como a transmissão dessas reflexões ao longo do tempo.

PALAVRAS-CHAVE: Górgias, Sofística, Retórica, Aristóteles, Modelo Jurídico.

ABSTRACT: The present research aims to analyse the method of discourse employed by Gorgias in his work entitled "The Defense of Palamedes" through an analytical philosophical appreciation of the text, based on the legal model adopted in Greece in the 5th century BC The research has as specific objectives to investigate the Gorgian method of defense in the Defense of Palamedes, to identify, in the same work, the rhetorical elements of persuasion employed by Gorgias, to understand the legal principles used by Gorgias in the work in question and to estimate which would be the real intention of Gorgias with the presentation of the Defense of Palamedes. We will deal in detail with two basic points pointed out in Palamedes' speech, which would be the absence of evidence and the verisimilitude of the allegations. An approach to these points will also be made in the light of the rhetorical manual proposed by Aristotle. The theme is relevant to the understanding of the development of philosophical reflections on legal processes and the means to effect persuasion. The understanding of these questions from ancient thinkers will shed light on the current discussions on these themes, enabling us to understand important aspects of this development as well as the transmission of these reflections over time.

KEYWORDS: Gorgias, Sophistication, Rhetoric, Aristotle, Legal Model. 


\section{INTRODUÇÃO}

A presente pesquisa utilizará como texto base a Defesa de Palamedes, escrito pelo sofista Górgias de Leontinos, obra que tem como personagem principal o próprio Palamedes.

A noção da figura do Palamedes, bem como do modelo jurídico adotado na Grécia durante o século V a.C. são de suma importância para a compreensão de uma das questões que norteiam a presente pesquisa, que é aferir para qual finalidade foi composto o Palamedes?

Palamedes é um personagem da mitologia grega, muito conhecido por sua inteligência. Segundo conta a tradição, a ele é atribuída à invenção de algumas letras do alfabeto, os números, as noções de peso e medida, algumas táticas militares e também a criação de jogos de tabuleiro.

Palamedes foi acusado por Odisseu de traição ao trono grego, acusação esta que culminou com a morte do nosso agente principal. Séculos depois, Górgias traz à tona o caso Palamedes e elabora uma defesa a qual deveria ter sido apresentada por Palamedes perante o trono grego, considerando que, se tivesse seguido o referido modelo, talvez tivesse se livrado da condenação de morte. Para tanto, Górgias se vale de algumas regras jurídicas que eram adotadas a época, em que pese no século V a.C. o ordenamento jurídico grego não ser bem estruturado, a exemplo da figura do advogado, que ainda não era reconhecida com profissão.

Para elucidar essa questão principal, analisaremos os argumentos do "Palamedes" tendo em vista dois tipos principais: provas e verossimilhança, com o auxílio da Retórica de Aristóteles, que demonstra em muitas partes conhecer e seguir o pensamento georgiano quanto à retórica. Por fim, se buscará compreender se seria $A$ Defesa de Palamedes um modelo jurídico a ser seguido por seus alunos, bem como quaisquer daqueles que se interessasse por sua obra, ou uma espécie de propaganda de "marketing pessoal".

Sobre Górgias, convém registrar que, em pese ser considerado por estudiosos do movimento sofista como um de seus mais célebres representantes, as suas obras são pouco estudadas, deste modo, um estudo sobre a obra Defesa de Palamedes, contribuirá com o enriquecimento das investigações a respeito dos elementos retóricos presentes nos discursos de Górgias, com destaque para os elementos jurídicos que permeiam o texto em análise, tomando como parâmetro, como dito anteriormente, o modelo de ordenamento legal adotado na Grécia Antiga, especialmente no século V a.C. 


\section{GÓRGIAS E O MODELO JURÍDICO DO FINAL DO SÉCULO V A.C.}

Górgias de Leontinos, um dos três filhos de Carmântides, nasceu em Leontino, colônia grega da Sicília, provavelmente entre os anos de 485 a 480 a.C. O que se sabe de fato é que, nos idos dos anos 427 a.C, Górgias fizera uma viagem para Atenas, cidade que se tornava cada vez mais promissora, para atuar como embaixador de Leontinos. Sua missão era persuadir o governo ateniense a prestar assistência militar ao seu povo contra Siracusa, tendo atingido o seu intento e voltado para sua cidade natal.

Untersteiner afirma que a ida de Górgias a Atenas é considerado o primeiro acontecimento com registro confiável e aponta ainda a vitória da persuasão de Górgias ante ao governo ateniense:

$\mathrm{O}$ primeiro acontecimento cronologicamente seguro de sua vida refere-se à embaixada que lhe foi outorgada por sua pátria, Leontino, e que ele comandou em 427 a.C., em Atenas para pedir ajuda contra Siracusa, que se tornava cada vez mais poderosa, a ponto de provocar a união, para seu próprio dano, das cidades de Calcídia. Górgias, que sem dúvida referiu-se ao tratado de aliança de 433 a.C., conseguiu seu objetivo, mas Atenas não se empenhou e a ação terminou em 425 a.C. com um fracasso, ainda que tenha sido a casa remota da intervenção de Atenas na Sicília. (UNTERSTEINER, 2012, p. 151).

É possível que afirmar que esta foi a primeira vez que Górgias chamou a atenção dos atenienses para seus discursos, ganhando notoriedade em Atenas.

Há quem afirme que Górgias foi o pai da sofística, movimento filosófico, denominado de "Os Sofistas", do grego sophos, que significava sábio, ou ainda perito, nos termos do registro feito por Kerferd (2003, p. 45):

O nome sofista está claramente relacionado com as palavras gregas sophos e sophia, comumente traduzidas por "sábio" e "sabedoria". Conforme explicação corrente, adotada tanto nos nossos dicionários como em nossas histórias da filosofia, esses termos sofreram uma espécie de evolução, quanto ao seu sentido de (1) habilidade em uma determinada ocupação, especialmente ofício manual, passando por (2) prudência ou sabedoria em questões gerais, especialmente sabedoria prática e política, para (3) sabedoria científica, teórica ou filosófica.

Tal corrente filosófica tinha por finalidade precípua ensinar técnicas de persuasão aos jovens atenienses, de modo que estes pudessem discursar e expor suas opiniões sobre quaisquer assuntos. 
Uma das características mais marcantes de Górgias era justamente a sua técnica de argumentação e ensino. Ele considerava de suma importância à análise da intenção das palavras que eram proferidas no discurso, ao fim de que pudesse ser alcançada a justificativa mais apropriada ao conhecimento de si próprio e dos demais ouvintes.

Merece destaque a observação feita por Untersteiner (2012, p. 150), ao afirmar que "Górgias tornou-se orador e quis transformar a aparência em realidade, por meio da persuasão de seus ouvintes. Assim atribuiu também à física e à erística certa força capaz de despertar a aparência da verdade". Demonstrando que o poder persuasivo de Górgias era realmente algo notável e merecedor de observação.

Sobre o poder de persuasão de Górgias, Capizzi assevera:

Com efeito, Górgias tinha em mente uma só ideia séria: convencer seu auditório de que qualquer tese é sempre demonstrável, desde a inocência de Helena e de Palamedes até a inexistência da realidade com a condição de conhecer-se muito bem este "grande poderoso" que é o raciocínio; e de que, em consequência, aquela que deseja ser o vencedor no tribunal ou na ágora deve confiar-se, pagando o preço corrente à escola dos retóricos. (MARQUES, 2017, p. 76)

Górgias traz uma nova forma de apreciação dos discursos, transportando os sentimentos do homem para o centro da fala, por entender que o $\operatorname{logos}^{1}$ seria capaz de levar o homem a tomar consciência das coisas a qual está imerso.

O leontino afirma ainda que a bondade de um discurso está intimamente ligada à finalidade para a qual o mesmo está sendo utilizado, tendo em vista a forte influência que ele exerce sobre o íntimo de seus interlocutores.

Como dito, esta investigação tem por objetivo analisar a argumentação jurídica adotada por Górgias na Defesa de Palamedes. Para tanto, é mister que se faça uma ponderação sobre o modelo jurídico adotado em Atenas durante o século V a.C, que serviu de base para a elaboração do discurso do leontino.

Com relação à estrutura textual, tanto Górgias quanto Antifonte usaram a mesma forma de apresentação: uma sequência de quatro discursos, sendo dois para a defesa e dois para a acusação, distribuídos de forma alternada. Já no tocante ao modo de apresentação destas duas obras

\footnotetext{
${ }^{1}$ A palavra grega logos possui uma série de significados. Seus principais usos dizem respeito a três áreas a saber: a primeira é a da linguagem, onde recebe o significado de fala, discurso, declaração. E é neste sentido que o logos é empregado pelos sofistas. A segunda está na área do pensamento, significando, portanto, reflexão, raciocínio, explicação. Por último, temos o logos na área do mundo, tratando especificamente sobre a capacidade que os homens possuem de falar e pensar, a exemplo da criação de princípios, fórmulas e leis naturais.
} 
especificamente, é possível de afirmar que tanto Górgias quanto Antifonte, como bons retóricos que eram, escolheram este modelo (discursos de defesa e acusação alternados) como recurso facilitador de compreensão. Ao dividir o texto da maneira que foi apresentada, os sofistas almejavam que os ouvintes pudessem compreender melhor os posicionamentos de cada parte e, assim, tirar suas próprias conclusões.

Por muito tempo, afirmou-se que o direito teria surgido na cultura romana, o que não é verdade $^{2}$. O que ocorre é que o sistema jurídico grego não foi muito ainda estudado. Talvez isto se deva ao distanciamento temporal, bem como ao estilo de modelo jurídico adotado na cultura ocidental, que em muito se assemelha ao direito romano ${ }^{3}$. Mas uma informação que se deve ter em mente é que o direito grego existiu e serviu de base para algumas conformações do direito romano. Como afirmado acima, Górgias e Antifonte são dois grandes representantes da retórica jurídica da Grécia, assim como Aristóteles, cujas obras que servem de sustentáculo para a discussão de vários temas no âmbito do estudo do direito, conforme será demonstrado no presente trabalho por meio da análise da Defesa de Palamedes sob a ótica da Retórica.

Ressalte-se que, na Grécia Antiga, não existia a figura do advogado como conhecemos hoje. Caberia ao próprio acusado levantar a sua defesa e utilizar os mais variados meios de prova para tentar demonstrar a sua inocência, ou até mesmo a sua explicação para ter cometido de fato o ato considerado delituoso.

\section{ARGUMENTOS E TAXONOMIA DA DEFESA DE PALAMEDES}

A principal questão que norteia a presente pesquisa diz respeito à natureza da Defesa de Palamedes. Ela pode ser considerada um modelo jurídico a ser seguido, servindo assim como material didático, ou seria uma peça de propaganda de Górgias?

Com relação à estrutura textual Górgias utilizou como forma de apresentação a seguinte sequência: texto divido em quatro discursos, sendo dois para a defesa e dois para a acusação, distribuídos de forma alternada, como meio de facilitar o entendimento das etapas de uma defesa

\footnotetext{
${ }^{2}$ Conforme restou demonstrado na tese de doutorado elaborada por Guilherme Roman Borges, como requisito para obtenção do título de Doutor no Programa de Pós-Graduação em Direito, área de Filosofia e Teoria Geral do Direito, da Faculdade de Direito, do Setor de Ciências Jurídicas, da Universidade de São Paulo, sob orientação do Professor Titular Dr. Técio Sampaio Ferraz Junior.

${ }^{3}$ Registre-se que, em muitos cursos de direito ofertados no país, a matéria Direito Romano é disciplina obrigatória e serve de introito para o estudo dos mais variados ramos do direito compreendidos atualmente.
} 
jurídica no Tribunal Ateniense. Desta forma, os ouvintes poderiam compreender melhor os posicionamentos tanto da acusação como da defesa e, assim, tirar suas próprias conclusões.

Górgias começa o texto da Defesa de Palamedes tratando sobre a morte. Segundo ele, todos nós já nascemos condenados a morrer. Basta saber se essa morte será justa ou injusta; se será violenta; ou ainda, se eivada de culpa de algum ato praticado em vida.

No terceiro parágrafo Górgias trata da pessoa de Odisseu. Seria ele um homem bom? O que teria motivado Odisseu a acusar Palamedes de traição? Górgias deixa claro que, caso fosse verdadeira a imputação do crime de traição a Hélade, praticado por Palamedes, Odisseu deveria ser considerado um homem excelente, afinal ele defendeu a pátria e os genitores, livrando a sociedade de um traidor. No entanto, caso o acusador tenha levantado a questão da traição apenas por inveja, perfídia ou ainda desonestidade, ele não passa de um homem mau, o pior dos homens.

No quarto parágrafo, Górgias levanta uma das questões mais importantes do seu texto: como elaborar uma defesa de algo que não aconteceu? Sob a ótica de Palamedes, o fato de a traição não ter acontecido gera uma dificuldade enorme na elaboração da defesa, uma vez que não se sabe ao certo o que falar nem por onde começar a defesa, nem quais os melhores argumentos a serem utilizados.

A partir do quinto parágrafo, Górgias começa a defesa propriamente dita. Ele inicia suas alegações negando a ocorrência do fato, sob a justificativa de que sabe claramente o que fez, e levanta o questionamento de como alguém poderia saber de algo que não aconteceu.

Mais adiante, o autor tenta mostrar de forma lógica a incapacidade de Palamedes de trair a Hélade, sempre mostrando meios de como poderia ter ocorrido a traição, mas em seguida rechaça cada hipótese. E aqui convém destacar que Górgias sempre retorna ao discurso de que os fatos nunca ocorreram, tratando somente de suposições acerca de como poderia ter se efetivado o crime pelo qual Palamedes estava sendo acusado.

No nono parágrafo, Górgias levanta pela primeira vez no texto a precariedade da acusação, visto que ela não possui nenhum suporte de comprovação, ou seja, não há nenhuma prova, ainda que testemunhal, de que os fatos ocorreram como Odisseu apresentou. E segue, no parágrafo décimo primeiro trazendo outro questionamento, que seria: se houvesse uma testemunha e ela fosse um escravo, seria uma prova confiável? Estaria o escravo sendo sincero em sua fala ou estaria apenas afirmando a existência de algo que realmente não presenciou somente por interesses, necessidades materiais ou ainda pelo anseio da liberdade? 
Nos parágrafos décimo terceiro, décimo quinto e décimo sexto, a "Defesa de Palamedes" traz um apelo aos ouvintes e coloca-os dentro da defesa, fazendo elogios e clamando para que eles se lembrem da vida passada do acusado, como forma de deixar claro que a prática do crime de traição não lhe traria nada de útil.

Convém destacar que, no parágrafo décimo quarto, ao afirmar que seria impossível que Palamedes dominasse sozinho o povo bárbaro, Górgias estaria também fazendo uma espécie de elogio a estes povos, ao trazer à tona que seria tolice acreditar que uma pessoa pudesse escolher “a escravidão em vez da realeza", "o pior em vez do melhor".

Do parágrafo décimo sétimo até o vigésimo segundo, Górgias demonstra a vida difícil que leva aquele que comete traição e reforça que não possui nenhum interesse em tal ato, posto que não lhe traria nenhum benefício, somente um mal para si próprio, coisa que ninguém desejaria.

Em verdade, a traição beneficiaria somente os seus inimigos e ela estaria sendo voltada não somente para a Hélade, mas traria consequências ruins para seus familiares, amigos e até mesmo para a sua história, e segue enumerando todos os infortúnios pelos quais iria passar em decorrência da traição.

O texto traz a fala de Palamedes diretamente ao acusador entre os parágrafos vinte e dois e vinte e sete, questionando, de início, em que se sustenta a acusação e volta a tratar da problemática da falta de provas que possam dar suporte a acusação.

Górgias levanta mais uma vez uma questão muito importante para qualquer tipo de investigação, que seria a ausência de provas, mais precisamente a testemunhal. A ausência de testemunhas por parte do acusador é inaceitável. Já a falta desta prova por parte de quem está sendo acusado é passível de admissibilidade, pois não se tem como testemunhar fatos que não aconteceram. Vejamos:

Dirás talvez que é o mesmo nem tu apresentar testemunhas de coisas que, como tu dizes, aconteceram, e nem eu de coisas que não aconteceram. Mas não é o mesmo: pois o que não aconteceu é impossível testemunhar de qualquer modo, mas acerca do que aconteceu não só é impossível, mas fácil; não só fácil, mas também necessário. Mas tu não encontraste testemunhas, nem sequer falsas testemunhas, enquanto a mim não é possível encontrar nenhuma das duas coisas.

Ainda com relação à fala de Palamedes a seu acusador, Górgias põe em questão a inteligência de Odisseu, ao sentenciar que nenhum homem sábio faz acusações com base em 
suposições, opiniões. Pelo contrário, a imputação de um fato, seja ele criminoso ou não deve ser sempre pautado na verdade.

Que, portanto, não conheces aquilo de que me acusas, é evidente. Resta que não sabendo, tu supões. Então tu, o mais audacioso de todos os humanos, confiando na opinião, a coisa menos confiável, e não sabendo a verdade, ousas pedir a pena de morte a um homem? Que tipo de ato sabes que ele praticou? De fato, opinar a respeito de tudo é comum a todos, e nisso em nada tu és mais sábio que os outros. Não se deve confiar nos que opinam, mas nos que sabem, nem considerar a opinião mais credível que a verdade, mas, ao contrário, a verdade mais que a opinião.

Palamedes encerra sua fala a Odisseu chamando-o de mentiroso e ainda afirmando que poderia fazer o mesmo para com ele, ou seja, levantar acusações, mas prefere assim não fazer, pois anseia livrar-se da acusação de traição pelas suas benfeitorias.

Do parágrafo vigésimo oitavo em diante, Palamedes dirige sua atenção aos juízes. Inicia esta fase de sua defesa apelando aos juízes e fazendo uma valorização da sua pessoa, inclusive destacando que não tem nada em seu passado que o torne uma pessoa indigna e capaz de cometer traição e frisa que o discurso do acusador assemelha-se ao crime de injúria, tendo ele como vítima.

Górgias relembra também neste ponto todas as invenções feitas por Palamedes e o poder e utilidade que elas possuem para todos, numa espécie de autoelogio. Destaca ainda que quem dedica seu tempo a fazer o bem, não sobra espaço para pensar e fazer coisas ruins, de modo que uma vez que não dedica seu tempo a prejudicar os outros, espera também não ser prejudicado, pugnando por um julgamento justo e com base na verdade.

Convém chamar atenção para o parágrafo trinta e um, ainda na parte do apelo aos juízes, onde vemos claramente nesses trechos uma característica do marcante sofista, no que diz respeito ao sentimento de empatia, o se colocar no lugar do outro, a equidade que deve haver no trato com o próximo, quando Palamedes diz: "se eu próprio em nada vos prejudico, em nada devo ser prejudicado por vós".

O texto relata ainda o perigo que pode acarretar a tomada de decisão errada, principalmente neste caso que tem como pena a morte, uma vez que não há como devolver a vida de que já morreu. É algo que não poderá nunca ser consertado. De outro modo, Górgias aponta que para um homem bom, por vez é preferível à morte, a uma vida com uma reputação vergonhosa. 
Nas linhas finais da Defesa de Palamedes, Górgias atenta para o fato de que a culpa pela morte de Palamedes não recairá sobre Odisseu, mas sim sobre os juízes, únicos responsáveis pela decisão final do caso.

Por fim, Palamedes teria mais uma vez elogiado os juízes, ao afirmar que seria desnecessário fazer um breviário de tudo o quanto foi dito até o momento, por acreditar que os jurados estavam atentos a sua fala.

O discurso de Górgias na defesa de Palamedes leva em conta o modelo jurídico que era adotado na Grécia nos idos do século V a.C, qual seja, o acusado apresentava suas razões direcionadas ao júri, de modo a convencê-los de que não era o culpado do crime que lhe fora imputada a autoria.

Note-se que, em linhas gerais, que o ponto central de todo o discurso de Palamedes gira em torno da falta de prova, bem como a ausência de verossimilhança das possíveis alegações que teriam sido levantadas por Odisseu ao apresentar a acusação contra Palamedes perante o Tribunal Ateniense.

Tanto a falta de prova, quanto a ausência de verossimilhanças das alegações, são questões crucias em toda defesa judiciária. É por meio delas que pode ser demonstrada a fragilidade nos argumentos que levaram a imputação de um crime a uma pessoa. Sem prova, não é possível demonstrar a ocorrência do fato delituoso. Do mesmo, sem o liame entre a sucessão de fatos narrados, resta indemonstrável a materialidade do crime supostamente cometido. E é sobre este ponto específico que iremos discorrer a partir de agora.

\section{A PROBlemática da AuSÊnCIA de VerossimilhanÇa e PROVA, À LUZ da RETÓRICA DE ARISTÓTELES}

Como dito anteriormente, o discurso de Palamedes elaborado por Górgias, evidencia a todo o momento o fato de a acusação de Odisseu ter sido apresentada sem a apresentação de qualquer tipo de prova, bem como pela ausência de verossimilhança das alegações.

Tendo observado que o texto trata basicamente da questão da necessidade de demonstração dos fatos narrados, ou seja, a imprescindibilidade de provas, se tornou imprescindível trazer à tona o que dispõe Aristóteles em sua obra A Retórica, principalmente no que concerne aos discursos judiciários. 
De início, ressaltamos que, no entender de Aristóteles, para que orador faça demonstrações em seu discurso deverá fazer uso do entimema e do exemplo, sendo o primeiro derivado das probabilidades e dos sinais. São classificados como silogismos que se compõem de poucas proposições que não são necessariamente universais e verdadeiras, mas que em geral, são aceitas pela maioria das pessoas, de modo a facilitar a compreensão do discurso pelos ouvintes e nível de persuasão do orador. É a forma dedutiva da argumentação retórica. Já o exemplo tem por base fatos que já aconteceram e se repetiram numa quantidade de vezes $\mathrm{x}$, de modo que esse caráter repetitivo do evento imprime no ouvinte a sensação de que a informação passada é confiável e, por conseguinte, é verdadeira. Em síntese, o exemplo se utiliza de fatos passados para deduzir como serão os eventos futuros.

Ainda no tocante à diferença entre entimema e exemplo, Aristóteles (2005, p. 98) afirma que "demonstrar que, de certas premissas, pode resultar uma proposição nova e diferente só porque elas são sempre verdadeiras, a isso chama-se silogismo na dialética e a entimema na retórica".

O estagirita deixa claro ainda que um discurso baseado em exemplo não é menos confiável do que um baseado em entimema, quando diz: "Não são, portanto, menos persuasivos os discursos baseados em exemplos, mas os que se baseiam em entimemas são mais aplaudidos".

No "Palamedes", é possível verificar que Górgias não faz uso de exemplos, elaborando todo o seu texto por meio de entimemas, ora os demonstrativos (aqueles em que a conclusão provém de premissas com as quais acusação e defesa compartilham do mesmo pensamento), mas em boa parte do texto é utilizado o entimema refutativo (aqui, o discurso da defesa vai de encontro com o que prega o adversário), típico dos discursos judiciários.

Aristóteles (2005, p. 93) deixa claro que tanto a prova, quanto a verdade e a verossimilhança das alegações são pontos cruciais que devem ser demonstrados num discurso, ao lecionar que "É próprio de uma mesma faculdade discernir o verdadeiro e o verossímil, já que os homens têm uma inclinação natural para a verdade e a maior parte das vezes alcançam-na. E, por isso, ser capaz de discernir sobre o plausível é ser igualmente capaz de discernir sobre a verdade".

A prova é elemento essencial em qualquer processo judicial, e isto não é diferente em Atenas. E é sobre a importância da presença de provas e verossimilhança que Górgias no "Palamedes" traz uma série de provas que poderiam ter sido levadas ao tribunal, a exemplo de 
testemunhas, como forma de comprovação da acusação, bem como demonstra várias refutações para os mais variados meios e circunstâncias que poderiam ter se dado a traição à Hélade.

Ainda com o olhar voltado para "Defesa de Palamedes", temos que o ponto crucial do discurso ali presente se dá em torno da tentativa de demonstração da inocência de Palamedes ante a flagrante ausência de provas e verossimilhança das alegações levadas ao Tribunal por Odisseu. Desde o proêmio até o apelo final aos juízes, Górgias trata exaustivamente da ausência de provas que corroborem com a acusação, em especial a ausência da prova testemunhal.

Aristóteles, anos mais tarde em sua obra Retórica, deixa explícita a problemática da ausência de prova testemunhal, ponto este que, como dito anteriormente, é bem ressaltado por Górgias no Palamedes. Através do excerto que segue abaixo é possível ver uma clara ligação da Retórica com o Palamedes, sobre este tema:

Ao lidar com a evidência das testemunhas, os seguintes argumentos revelam-se úteis: se não se dispõe de testemunhas, deve-se argumentar que os juízes têm que decidir a partir do que é provável; que isso significa julgar "conforme a consciência"; que a probabilidade não pode se deixar corromper pelo suborno, e que jamais a probabilidade foi pega em flagrante perjúrio. Ao contrário, quando se dispõe de testemunhas, e o adversário não, pode-se argumentar que probabilidades não cabem à justiça e que não se teria sequer necessidade da evidência das testemunhas se os discursos bastassem para descobrir a verdade. (ARISTOTELES, 2017, p. 113).

O estagirita traz ainda outro ponto de bastante relevância para uma boa retórica judicial, que são os tópicos de refutação ou contestação. Tais pontos servem de guia para a defesa a ser apresentada no tribunal, são eles: este ou aquele fato não existe; não é prejudicial para todos ou para o acusador; não merece ou não tem a relevância apontada pelo acusador; não é injusto ou é pouco e não justifica o processo; não é objeto de desonra ou ainda que não acarretaram consequências.

Destaco como mais importante para o nosso estudo o primeiro tópico, que é o que se destina a provar que o fato não existiu, afinal, é sobre a tese que os fatos alegados por Odisseu não existiram que se digna toda a defesa de Palamedes, conforme demonstrado no parágrafo quinto da Defesa de Palamedes:

Que o acusador me acusa sem saber claramente, claramente sei; pois sei claramente nada ter feito dessas coisas; nem sei como alguém poderia saber o que não aconteceu. Mas se ele fez acusação supondo que as coisas se passaram 
assim, vos mostrarei de dois modos que não fala a verdade, pois nem querendo eu poderia, nem podendo eu quereria empreender tais feitos.

Aristóteles esclarece que é de suma importância em um discurso refutatório demonstrar que a acusação não possui fundamentos, arcabouços probatórios suficientes para a sua sustentação, e este é um dos aspectos fundantes da tese de Palamedes. Górgias se esmera em deixar bastante claro que a acusação de Odisseu é infundada, caluniosa e que não possui fidelidade com a realidade, conforme se avista da leitura do parágrafo 24 (vinte e quatro) da Defesa de Palamedes.

Ainda sob o aspecto da refutação, Aristóteles aduz que outro meio eficaz de fazê-lo é retribuir a acusação apresentada com outra acusação. Eis aqui mais um ponto de confluência entre as obras, quando Górgias traz no parágrafo 27 (vinte e sete) que Palamedes poderia contraacusar Odisseu: "Embora possa te contra-acusar de teres cometido muitos e grandes erros, antigos e novos, não quero: pois quero escapar dessa acusação não pelas tuas maldades, mas por minhas bondades. Para ti, era isso".

Note que Górgias afirma ser possível utilizar a técnica da contra-acusação, mas prefere não utilizá-la por entender que o seu caráter de homem bom será capaz de absorvê-lo do crime do qual está sendo acusado.

O estagirita traz ainda em sua obra Retórica, mais precisamente no livro II, traz algumas reflexões a respeito de vários sentimentos humanos, a exemplo do medo. Para ele, o orador pode disseminar o medo nos ouvintes mostrando que eles podem vir a "sofrer do mesmo mal" experimentado pelo próprio comunicador, ou de quem ele fala.

É possível ver em boa parte da Defesa de Palamedes, que Górgias apela para o lado afetivo dos ouvintes, de modo a despertar neles as mais variadas emoções, como a compaixão, o medo, e assim, tentar convencê-los de sua tese. Em síntese, o que o leontino quer demonstrar é que a manipulação dos sentimentos podem ser bons aliados em um discurso jurídico.

Esses são alguns pontos importantes no que diz respeito à tese jurídica que eram empregadas os Tribunais Gregos entre os séculos V e IV a.C, apresentados por Górgias na "Defesa de Palamedes" e que anos mais tarde apareceram também na Retórica de Aristóteles.

\section{PALAMEDES COMO TEXTO PEDAGÓGICO}


No que diz respeito à defesa de Palamedes elaborada por Górgias, alvo de estudo do presente trabalho, é possível notar que a intenção precípua do Sofista era mostrar a inocência do seu agente principal. Mas, assim como ocorreu na época, ele sabe que a compreensão não chega à mente de todos de forma uníssona, apesar de todo o seu empenho em demonstrar a sua tese por meio de argumentos lógicos, posto que a opinião pode levar ao engano. Explico melhor: ao transmitirmos nosso pensamento a outrem, em verdade estamos apenas repassando um logos que é diferente da coisa em si mesma.

A realidade pode ser algo bem diferente daquilo que esta sendo comunicado, pois a realidade em si passou modificações ao sair do mundo externo e entrar em contato o interno, o pensamento do orador. Desta feita, podemos concluir que nem sempre aquele que discursa conseguiu enganar, por assim dizer a sua plateia.

Tratando especificamente da defesa de Palamedes, embora o discurso apresente um caráter lógico, com sentenças afirmativas e que mostram a impossibilidade da suposta ação delitiva, em razão da ausência de provas, bem como pela falta de verossimilhança das supostas alegações que teriam sido utilizadas por Odisseu para judicializar o caso, há uma espécie de barreira que impede a pessoa de chegar ao conhecimento verdadeiro e essa barreira é justamente a eloquência do discurso.

Conforme demonstrado, tomando por base a retórica aristotélica, a falta de indícios básicos, que seriam a ausência de provas e verossimilhança das alegações, já deveria por si só isentar Palamedes da acusação que lhe estava sendo imposta. Mas não foi o que correu.

Convém pontuar que a função do orador é envolver o ouvinte no seu discurso. O desafio do orador é convencer o seu público a tal ponto que este se desprende dos fatos reais, muitas vezes até bem conhecidos e se deixa enganar com o logos que está sendo apresentado, logos este na maioria dos casos poderá nem ser a realidade em si mesma.

Desta forma, podemos concluir que, ao afirmamos que a verdade vem do logos, não podemos perder de vista que esse mesmo logos pode se apresentar de maneira diferente para cada pessoa. Como dito, a maneira como uma coisa se apresenta para uma pessoa não é a mesma que se apresenta para outra, posto que a realidade em si mesma sofre intensa influência das sensações, percepções que, de fato, não se apresentam e não são sentidas da mesma forma por todos.

Palamedes foi condenado porque, apesar de ter demonstrado de forma lógica que os eventos e as acusações que lhe estavam sendo imputadas, tomando por base a defesa elaborada 
por Górgias fossem claramente falsas, pois impossíveis de serem realizadas, elas não foram assim entendidas por todos os ouvintes, dado o logos de cada um.

Desta feita, tendo em vista que o discurso chega a cada pessoa de maneira diferente, não há como se falar em verdade absoluta.

Resta claro que em um discurso, seja ele feito em palanque, ou mesmo em tribunais, como foi o caso de Palamedes, o que importa é a capacidade do orador em transmitir o seu logos de maneira tão eficiente que isso se torne a verdade da maioria.

No caso de Palamedes, ficou demonstrada a ausência de qualquer tipo de comprovação de que a traição teria sido praticada, tampouco havia verossimilhança nas possíveis alegações que podem ter sido levantadas por Odisseu junto o Tribunal Ateniense.

Assim, diante do que fora estudado até o presente momento e, tomando por base que muitos dos artifícios utilizados e mencionado por Górgias na Defesa de Palamedes, fora anos mais tarde repetidos e compilados por Aristóteles na Retórica, nos leva a supor que a Defesa de Palamedes possa ter um caráter pedagógico para os sofistas e demais atenienses de uma forma geral, sendo necessário um maior aprofundamento na análise dos textos das fontes primárias e secundárias com fins de elucidar a problemática apresentada no presente trabalho.

\section{CONCLUSÃO}

Em que pese a literatura empregar maior esforço para tentar desqualificar os sofistas como filósofos, a leitura de bons textos sobre o período áureo desses pensadores são capazes de demonstrar as diversas contribuições que eles deixaram para toda a humanidade.

Os sofistas exerceram um papel muito importante no desenvolvimento da cidade de Atenas, especialmente quando falamos no aspecto educacional e político. Porém, não devemos esquecer as contribuições destes pensadores para o direito grego.

$\mathrm{O}$ ensino e a propagação dos discursos retóricos foram fundamentais para o desenvolvimento da arte de defesas jurídicas, especialmente na Atenas no século V a.C. e a obra de Górgias $A$ Defesa de Palamedes é um bom exemplo dessa constatação.

Ao fazermos uma leitura atenta e minuciosa do texto em análise, é possível verificar a presença de alguns elementos que são basilares para uma boa defesa jurídica, quais sejam: a 
verossimilhança das alegações e a questão da ausência de provas para o oferecimento de uma denúncia e, por conseguinte, formação de um processo judicial.

É notória a preocupação de Górgias com tais pontos durante todo o texto e esta preocupação pode ser vista também na obra Retórica de Aristóteles, constituindo tais elementos os pontos chaves e de encontro entre as teorias de boa retórica destes filósofos.

O empenho de Górgias em demonstrar a fragilidade da acusação feita por Odisseu a Palamedes, bem como o modo explanação utilizado, indica que a obra tenha um objetivo pedagógico. Além disso, Górgias é integrante do movimento sofista, grupo que, como dito anteriormente, é conhecido como professores.

No entanto, apesar de todos estes indícios, é imperioso, ao menos neste momento, uma maior investigação do tema para então emitir uma conclusão a respeito.

\section{REFERÊNCIAS BIBLIOGRÁFICAS}

ARISTOTELES. [384-322 a.C.]. Retórica. 2 ed., revista. [Obras completas de Aristóteles. Coordenação: António Pedro Mesquita. Tradução e notas: Manuel Alexandre Júnior, Paulo Farmhouse Alberto e Abel do Nascimento Pena]. Lisboa: Centro de Filosofia da Universidade de Lisboa, Imprensa Nacional-Casa da Moeda, 2005.

. Retórica. 1 edição. 1 reimpressão. Tradução, textos adicionais e notas: Edson Bini. São Paulo: Edipro, 2017.

BARBOSA \& CASTRO. Górgias: Testemunhos e Fragmentos. Lisboa: Colibri, 1993.

BORGES, Guilherme Roman. $O$ direito constitutivo: um resgate greco-clássico do Nóminon Éthos como Eutaksía Nómini e Dikastikí Áskisis. 2011. Tese (Doutorado em Filosofia e Teoria Geral do Direito) - Faculdade de Direito, Universidade de São Paulo, São Paulo, 2011. doi:10.11606/T.2.2011.tde-02052012-152859. Acesso em: 06/09/2019.

CAVAlCANTE, Gabrielle. Defesa de palamedes. Gorgias. 2016. Revista Archai: Revista De Estudos Sobre as Origens Do Pensamento Ocidental, (17), 201-218. Disponível em: < https://digitalis-dsp.uc.pt/jspui/bitstream/10316.2/38909/1/Defesa\%20de\%20Palamedes.pdf $>$.

Acesso em: 27/07/2020.

CASERTANO, Giovanni. Sofista. Tradução de José Bortolini. São Paulo: Paulus, 2010. 
CERQUEIRA, Fabio Vergara. As origens do direito ocidental da pólis grega. Disponível em: $<$ https://www.tjrs.jus.br/export/poder_judiciario/historia/memorial_do_poder_judiciario/memoria 1_judiciario_gaucho/revista_justica_e_historia/issn_1676-5834/v2n3/doc/04-Fabio.PDF $>$. Acesso em 06/06/2019.

DINUCCI, Aldo. Górgias de Leontinos. São Paulo, Oficina do Livro, 2017.

GADAMER, H. G. Verdade e método I. Traços fundamentais de uma hermenêutica filosófica. São Paulo: Editora Universitária São Francisco, 2005.

GAGARIN, M. Did the sophists aim to persuade? Rhetorica: A Journal of the History of Rhetoric, vol. 19, nº 3, 2001, pp. 275-291.

GUTHRIE, W. K. C. Os Sofistas. 2 ed. Tradução de João Rezende da Costa. São Paulo: Paulus, 2007.

JUNIOR, Licinio Nascimento de Almeida. Conjecturas para uma retórica do design [gráfico]. Rio de Janeiro: PUC-RIO, 2009. Tese (Doutorado), Departamento de Artes e Design, PUC-RIO, 2009. Disponível em: $<$ https://www.maxwell.vrac.pucrio.br/colecao.php?strSecao=resultado\&nrSeq=13975@,1>. Acesso em: 28/02/2020.

KERFERD, G. B. O movimento sofista. Tradução de Margarida Oliva. São Paulo: Edições Loyola, 2003.

MARQUES, Marcelo P. (org), Filosofia dos Sofistas: Hegel, Capizzi, Versényi, Sidgwick. Tradução de Verlaine de Freitas et al. São Paulo: Paulus, 2017.

MARTINS, Renata Renovato. A retórica de Górgias: considerações sobre o Górgias de Platão e sobre o Górgias histórico. Rio de Janeiro: PUC-RIO, 2011. 94f. Dissertação (Mestrado), Departamento de Filosofia, PUC-RIO, Rio de Janeiro, 2011. Disponível em: < https://www.maxwell.vrac.puc-rio.br/colecao.php?strSecao=resultado\&nrSeq=19315@1 >. Acesso em 31/09/2019.

NARDI, Roberto Fernandes De. As tetralogias de Antifonte: tradução e comentários. 2015. Dissertação (Mestrado em Letras Clássicas) - Faculdade de Filosofia, Letras e Ciências Humanas, Universidade de São Paulo, São Paulo, 2015. doi:10.11606/D.8.2016.tde-26012016-133014. Acesso em: 29/07/2019.

OLIVEIRA, Paulo de Salles. Metodologia das ciências humanas. São Paulo: Editora Unesp, 1998.

RESENDE, Marcus. A retórica política do cosmo social. Aracaju: Infographics, 2019. 
MARTINEZ, Josiane Teixeira. A defesa de Palamedes e sua articulação com o Tratado sobre o não-ser, de Gorgias. 2008. 146p. Tese (doutorado) - Universidade Estadual de Campinas, Instituto de Estudos da Linguagem, Campinas, SP. Disponível em: $<$ http://www.repositorio.unicamp.br/handle/REPOSIP/270752>. Acesso em: 31/01/2019.

NASCIMENTO, Joelson Santos. O entimema e o exemplo da retórica de Aristoteles. PROMETEUS - Ano 5 - Número 9 - Janeiro-Junho/2012.

SIDI, Pilar de Moraes.; CONTE, Elaine. A hermenêutica como possibilidade metodológica à pesquisa em educação. Revista Ibero-Americana de Estudos em Educação, Araraquara, v. 12, n. 4, p. 1942-1954, out./dez. $2017 . \quad$ Disponível em: $<$ http://dx.doi.org/10.21723/riaee.v12.n4.out./dez.2017.9270>. E-ISSN: 1982-5587. Acesso em 26/07/2020.

UNTERSTEINER, Mario. A obra dos sofistas: uma interpretação filosófica. Tradução de Renato Ambrósio. São Paulo: Paulus, 2012. 